\title{
The Influence of Service Quality, Product Quality, Price and Promotion on AyamPenyet Jakarta (APJ) Purchase Decisions on SM Raja Medan Branch
}

\author{
Ahmad Rasyiddin ${ }^{1}$, Endang Sulistya Rini' ${ }^{2}$ Fadli $^{2}$ \\ ${ }^{1,2}$ Master of Management Study Program on Postgraduate School of University of Sumatera Utara \\ Corresponding Author: Ahmad Rasyiddin
}

DOI: https://doi.org/10.52403/ijrr.20220146

\begin{abstract}
The purchase decision is the point at which the buyer has decided on a product, purchased it, and consumed it. Service quality, product quality, price, and promotion are all elements that influence purchasing decisions. The expected level of perfection in service is service quality, and maintaining control over that level of excellence will satisfy client desires. Service quality, product quality, price, and advertising are all elements that impact purchase selections. This study uses an associative quantitative technique to investigate the impact of service quality characteristics, product quality, pricing, and promotion on AyamPenyet Jakarta (APJ) consumer purchasing decisions at SM Raja branch. The study sample consisted of all APJ customers who made purchases at SM Raja's APJ store in December 2020, a total of 350 people. The samples were chosen via incidental sampling, which entails estimating the number of samples needed at the time of the research and obtaining 70 research samples. A questionnaire was utilised to collect data. Multiple linear regression is used to analyse data. Customer service, product quality, pricing, and promotion all have a favourable and significant impact on APJ purchasing decisions, according to the research and data analysis. Service quality influences APJ purchasing decisions in a good and significant way. Product quality influences APJ purchase decisions in a good and significant way. APJ purchasing decisions are influenced by price in a positive and significant way. Promotion has a small but considerable impact on purchasing decisions. In terms of recommendations for APJ, it is desired
\end{abstract}

that APJ may provide better customer service, particularly in terms of serving food, reacting to consumer concerns, and providing facilities and infrastructure. By paying attention to the quality of the components, APJ can maintain consistency in flavour, colour, temperature, portion, aroma, and shape.

Keywords: service quality, service quality, product quality, price, promotion and purchasing decisions

\section{BACKGROUND}

In Indonesia, the culinary industry is becoming increasingly competitive. This can be seen in the growing number of fast food culinary concepts that continue to emerge in Indonesia; in addition to the growing human population, fast food is also very much needed by many people due to its convenience, which leads to purchases. The success of the culinary industry is primarily driven by the correct marketing strategy, which may continually support the firm ahead of its competition, resulting in product and service quality that meets customer expectations and, as a result, influences purchase decisions.

AyamPenyet Jakarta (APJ) is one of the culinary marvels in Medan, which has been impacted by the culinary industry's rapid growth and rivalry. Despite the fact that the production and marketing quality procedures were followed to the letter, sales at APJ Jalan Sisingamangaraja have decreased, particularly in the previous three 
years (2017-2019).APJ is also up against Ayat Penyet Joko Solo, AyamPenyet Surabaya, AyamPenyet Ria, and other Chicken Penyet restaurants in Jakarta. Various issues, including as service quality, product quality, price differences, and so on, have contributed to APJ Jalan Sisingamangaraja's drop in purchasing decisions.

According to the following description, service quality of APJ Jalan Sisingamangaraja is poor, and product quality has deteriorated during the last three years. In addition to service and product quality, the price of chicken penyet offered is quite high, despite the fact that the price of chicken penyet provided by APJ does not change, and people's purchasing power is weak owing to the community's current adverse economic situation. Similarly, APJ's promotions in the last few years have been fairly limited. All of these has an impact on the public's decision to buy APJ.

Service quality is one of the many elements that influence purchasing decisions. The concept of service quality, according to Kotler (2012: 83), is any action or activity that can be given by one party or another and is essentially intangible and does not result in ownership. The behaviour of producers in order to meet the requirements and desires of consumers in order to achieve consumer pleasure is referred to as quality of service. This behaviour can occur during, during, and after the transaction, according to Kotler. In general, a high level of service quality will lead to high levels of customer satisfaction and frequent repeat transactions. When a service provider produces service quality that exceeds or is comparable to client expectations, it is referred to as "very good." When a customer receives service that falls short of his expectations, the quality is referred to as poor. Product quality, in addition to service quality, influences purchase decisions.

Laksana (2013:67) defines product quality as "anything physical and nonphysical that can be supplied to consumers to fulfil their wants and needs." Meanwhile, product quality, according to Deming (2012:48), is the compatibility of a product's quality with market or consumer needs. So, based on the foregoing understanding, product quality is an effort to meet or exceed customer expectations, where a product's quality is in accordance with predetermined quality standards, and quality is an ever-changing condition because consumer tastes and expectations for quality products are constantly changing.

Price has an impact on purchase decisions as well. A price is the monetary value of a thing (Nela, 2012:5). Price can be considered as a criterion for product quality based on these criteria. Consumers will purchase a high-quality goods if the pricing is reasonable and in line with the product's quality.

In addition to service quality, product quality and price are promotions, where according to Abdurachman, (2014: 36 ), promotions are messages that are communicated so that superior product quality can be conveyed to customers. Promotions can bring benefits to both entrepreneurs and customers. The advantage for customers is that customers can manage their spending better, for example, a customer who reads an advertisement, he can buy cheaper goods or product quality. The advantage for entrepreneurs is that promotions can avoid competition based on price, customers buy goods or product quality because they are attracted to the quality of the brand. Promotion not only increases sales but also balances product quality. As a result of promotions that aim to arouse desire or stimulate purchases so that customers feel confident so they want to buy. The activities carried out include giving buy two get one free, and others.

Polla, et al, 2013, shows that price and location have a significant effect on consumer purchasing decisions, promotions have a positive and insignificant effect, while service quality has a negative and insignificant effect on consumer purchasing decisions. Price, promotion, location and 
service quality simultaneously have a significant effect on consumer purchasing decisions. PT. Indomaret Manado Unit Jalan Sea should further improve marketing strategies in price, promotion, location and quality of service to improve purchasing decisions. The results of Supirman's research (2016) show that the variable completeness of product quality, price and location simultaneously has a significant effect on consumer purchasing decisions at Eramart Sentosa Samarinda, the price and location variables partially have a significant effect while the completeness of product quality partially has no effect on consumer purchasing decisions at Eramart Sentosa Samarinda.

\section{Service Quality}

According to Tjiptono (2012:260) service quality is the level of excellence expected and control over the level of excellence will fulfill customer desires. The quality of service referred to in this study is the quality and excellence of the quality of service provided by APJ to consumers, namely the ability to serve consumers either directly or indirectly. Service quality indicators include:

1) Direct Evidence (Tangibles)

2) Reliability (Reliability)

3) Responsiveness

4) Guarantee (Assurance)

5) Attention (Empathy)

\section{Product Quality}

According to Mowen and Minor (2012: 90), product quality is an evaluation made by consumers on the goodness of the decision to purchase goods or services. Product quality describes the extent to which APJ's ability to meet and satisfy consumer needs. The quality of quality food products can be measured by the taste and attractive shape of the food. The quality of food products referred to in this study is the quality of Jakarta Penyet Chicken (APJ) as the quality of food products served to consumers. Product quality indicators include:
1) Color

2) Appearance

3) Portion

4) Shape

5) Temperature

6) Texture

7) Aroma

8) Taste

\section{Price}

According to Kotler and Armstrong (2013: 345), price is a number of values charged for a quality product or service provided by consumers to benefit from using quality products or services. The price referred to in this study is the price of APJ Jalan Sisingamangaraja which is sold to consumers. Price indicators include:

1) Price affordability

2) Price match with product quality

3) Price competitiveness

4) Price match with benefits

\section{Promotion}

Promotion according to Sangaji (2013: 18) is a type of marketing activity aimed at encouraging consumer demand for the quality of products offered by producers or sellers making it attractive for consumers to make a decision to buy a quality product. The indicators of the promotion are:

1) Promotion Quality

2) Promotion Quantity

3) Promotion Range

4) Promotion Time

5) Accuracy of Promotional Goals

\section{Purchase Decision}

According to Kotler (2013), purchasing decisions are stages taken by consumers before making a decision to buy a quality product. The existence of consumer purchasing decisions on a product quality can be influenced by various factors. The first factor is the attitude of others and the second factor is the situational factor. Therefore, the purchase intention of APJJalan Sisingamangaraja by consumers can be influenced by the quality of service, product quality, price and promotion set. Purchase decision indicators include: 
1) Needs Recognition

2) Information Search

3) Alternative Evaluation

4) Purchase Decision

5) Behavior after Purchase

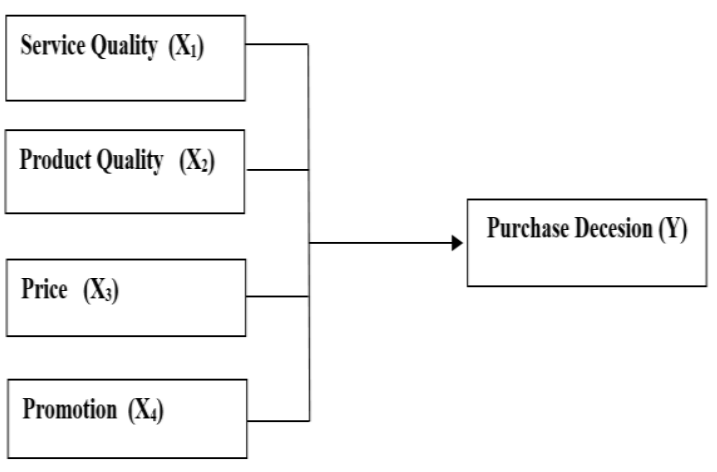

Figure 1: Conceptual Framework

\section{Hypothesis}

1. Quality of service has a significant effect on purchasing decisions at APJ Jalan SisingamangarajaBranch

2. Product quality has a significant effect on purchasing decisions at APJ Jalan SisingamangarajaBranch

3. Price has a significant effect on purchasing decisions at APJ Jalan SisingamangarajaBranch

4. Promotion has a significant effect on purchasing decisions at APJ Jalan SisingamangarajaBranch

5. Simultaneously service quality, product quality, price and promotion have a significant effect on purchasing decisions at APJ Jalan Sisingamangaraja Branch

\section{RESEARCH METHOD}

This study uses a causal associative approach using a quantitative approach. The population in this study are consumers who buy at AyamPenyet Jakarta during December 2020 with a total of 350 people. The population of this study amounted to 350 , so the authors set a sample of $20 \%$ of the total population, namely 70 people. This is in accordance with the opinion of SuharsimiArikunto, (2010: 109), if the subject is less than 100 people, all of them should be taken, if the subject is large or more than 100 people can be taken $10-15 \%$ or $20-25 \%$ or more. The sampling system is incidental, which according to Sugiyono (2017: 67), is a sampling technique based on coincidence, that is, anyone who coincidentally/meets with a researcher can be used as a sample; if it is deemed that the person who happened to be met is suitable as a data source.

The research instrument according to Sugiyono (2015:102) is a unit of tool used to measure natural and social phenomena that are observed. The instruments used in this research are in the form of questionnaires and questionnaires which are compiled based on indicators of research variables. Linear regression testing explains that there is an effect of service quality, product quality, price and promotion on purchasing decisions. The results of regression analysis with calculations using SPSS V.20 software.

\section{RESULT AND DISCUSSION Hypothesis Test ( $\mathrm{T}$ test)}

\begin{tabular}{|c|c|c|c|c|c|c|}
\hline & & & $\begin{array}{l}\text { able 1: T Test } \\
\text { oefficients }^{\mathrm{a}}\end{array}$ & & & \\
\hline & & Unstandardize & Coefficients & Standardized & $\bar{T}$ & Sig. \\
\hline & & $\mathrm{B}$ & Std. Error & Beta & & \\
\hline & (Constant) & 1.146 & 1.438 & & .797 & 0.428 \\
\hline & X1 Service Quality & 0.772 & 0.427 & 0.817 & 2.117 & 0.075 \\
\hline 1 & X2 Product Quality & 0.115 & 0.334 & 0.114 & 1.991 & 0.731 \\
\hline & X3 Price & 1.782 & 0.685 & 1.987 & 2.603 & 0.011 \\
\hline & X4 Promotion & -1.722 & 0.750 & -1.948 & 2.296 & 0.025 \\
\hline
\end{tabular}

Based on the results of calculations using the SPSS Version 20 program, in the table it can be seen that the correlation value between price and purchase decisions is 
2,603, while the correlation value between service quality is 2,117 , product quality is 1,991 , and promotion is 2.296 . It can be seen that the difference in correlation between service quality, product quality, price and promotion with purchasing decisions when compared to $\mathrm{t}$ table 1980 with a standard of 0.5 states that the correlation of variable $\mathrm{x}$ to variable $\mathrm{Y}$ has a strong relationship.

The occurrence of the influence of variables $\mathrm{X} 1, \mathrm{X} 2, \mathrm{X} 3$ and $\mathrm{X} 4$ on the variables that can be seen that:

1. The t-count price of $\mathrm{X} 1$ is 2.117 while the $\mathrm{t}$-table is 1.980 this shows that the $\mathrm{t}-$ count is smaller than t-table and there is an effect between X1 (Service Quality) on the $\mathrm{Y}$ variable (Purchase Decision) with a significant effect

2. The t-count price of $\mathrm{X} 2$ is 1.991 while the $\mathrm{t}$-table is 1.980 this shows that the $\mathrm{t}$ count is smaller than t-table and there is an effect between X2 (Product Quality) on the $\mathrm{Y}$ variable (Purchase Decision) with a significant effect.

3. The t-count price of $\mathrm{X} 3$ is 2.603 , while the $\mathrm{t}$-table is 1.980 this indicates that the $\mathrm{t}$-count is greater than t-table and there is an effect between X2 (Price) on the $\mathrm{Y}$ variable (Purchase Decision) with a significant effect
4. Promotion t-count $\mathrm{X} 4$ is 2.296 , while $\mathrm{t}$ table is 1.980 this shows that $\mathrm{t}$-count is greater than t-table and there is an effect between X2 (Promotion) on variable Y (Purchase Decision) with a significant effect.

It can be seen that the correlation between variables with a positive relationship direction (no negative sign) means that the larger the independent variable, the more the dependent variable will increase, and vice versa if the smaller the independent variable, the smaller or lower the dependent variable (purchase decisions). The significance level of the two-sided correlation coefficient of the output (measured from probability) generated by the correlation between the two independent variables (price and promotion and product quality) with the dependent variable (purchase decision) is very real because the probability of 0.000 is below 0.05 or $=5 \%$.

\section{Simultaneously test (F test)}

This test was conducted to determine whether service quality, product quality, price, promotion simultaneously (simultaneously) significantly influence purchasing decisions at the $95 \%$ confidence level and Test of level 5\% with the recommended F-test.

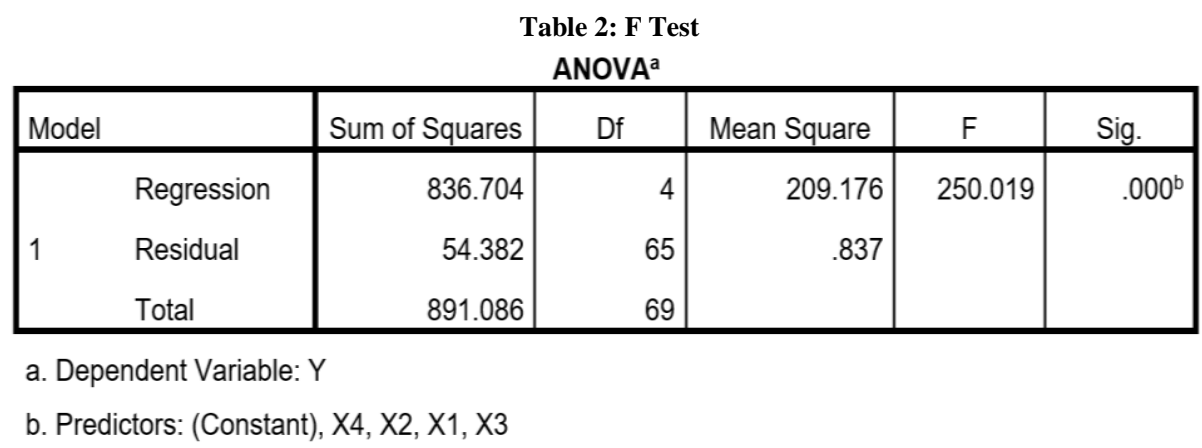

Based on the table, Fcount is $250,019>$ from Ftable 1.97 with a significant level of 0.000 . Because Fcount is greater than Ftable and the probability of 0.000 is much smaller than 0.05 , so Reject Ho (Accept H1), it is concluded that service quality, product quality, price and promotion simultaneously have a positive and significant effect on purchasing decisions. Thus the previous hypothesis (H1) is accepted. 


\section{R Test (Determinant)}

Table 3: R Square
Model Summary
\begin{tabular}{|l|r|r|r|r|}
\hline Model & R & R Square & $\begin{array}{c}\text { Adjusted R } \\
\text { Square }\end{array}$ & $\begin{array}{c}\text { Std. Error of the } \\
\text { Estimate }\end{array}$ \\
\hline 1 & $.969 \mathrm{a}$ & .939 & .935 & .91468 \\
\hline
\end{tabular}
a. Predictors: (Constant), X4, X2, X1, X3
b. Dependent Variable: Purchase Decesion

If the independent variable is more than one, then it is better to see the ability of the variable to predict the dividend variable, the value used is the adjusted $R^{2}$ value. The adjusted $\mathrm{R}^{2}$ value of 0.935 means that the dividend variable can be explained by the dividend variable of $93.5 \%$. In other words, changes in purchasing decisions can be explained by the four independent variables, and the remaining $6.5 \%$ is explained by other factors not included in this study.

\section{CONCLUSION}

1. There is a positive and significant influence between Service Quality on Purchase Decisions at APJ Jalan Sisingamangaraja Medan Branch.

2. There is a positive and significant effect between Product Quality on Purchase Decisions at APJ Jalan Sisingamangaraja Medan Branch.

3. There is a positive and significant effect of price on purchasing decisions at APJ Jalan Sisingamangaraja Medan Branch.

4. There is a positive and significant influence between promotions on purchasing decisions on APJ Jalan Sisingamangaraja Medan branch.

5. Simultaneously service quality, product quality, price and promotion affect the quality of purchases at APJ Jalan Sisingamangaraja Branch

\section{Acknowledgement: None}

\section{Conflict of Interest: None}

\section{Source of Funding: None}

\section{REFERENCES}

1. Abdurachman. 2004. Jurnal Manajemen \& Kewirausahaan. Surabaya: Liberty
2. Andi. Usmara. 2013. Strategi Baru Manajemen Pemasaran. Yogyakarta: Amara Books.

3. Andi. Tjiptono, F. 2012. Prinsip-prinsip Total Quality Service (TQS). Yogyakarta: Andi.

4. Arikunto,Suharsimi. 2014, Prosedur Penelitian :Suatu Pendekatan Sistem. Jakarta: Rineka Cipta

5. Basu Swasta, Hani, Handoko, 2015, Manajemen Personalia dan Sumber Daya Manusia. Yogyakarta: Liberty.

6. DayuRizki Tanita,2017, Pengaruh Kualitas pelayanan, Harga, Promosi Dan Kualitas produk Terhadap Keputusan Pembelian Pada Makanan Cepat Saji KFC Coffee Kedaton Bandar Lampung

7. Deming, 2012, Manajemen Pemasaran Modern,. Edisi Kedua, Yogyakarta : Liberty

8. Departemen Pendidikan dan Kebudayaan, 2013, Kamus Besa Bahasa Indonesia, Jakarta: Depdikbud.

9. Devi Reka Mayasari, 2012, Pengaruh Kualitas pelayanan Terhadap Keputusan Membeli Es Krim Walls di Chandra Supermarket Tanjung Karang Bandar Lampung

10. DewiSinta, 2014. PengaruhKualitasproduk, harga dan kualitas pelayanan terhadap keputusan pembelian konsumen Ayam Goreng Nelongso Cabang Jl. Soekarno Hatta Malang

11. Ekawati Rahayu Ningsih, 2018, Manajemen Pemasaran (Kudus : Nora Media Interprisse.

12. Fandy Tjiptono, 2012, Strategi Pemasaran Edisi 1 (Yogyakarta: Andi Offset.

13. Febriano Clinton Polla, dkk, 2013, PengaruhHarga, promosi dan Lokasi dan Kualitaspelayananterhadap keputusan pembelian konsumenPT. Indomaret Manado Unit Jalan Sea.

14. Handoko, T.Hani, 2013, Manajemen Pemasaran, Jakarta : Bumi Aksara.

15. Jackson R.S. Weenas,2013, Kualitas produk, Harga, Promosi Dan Kualitas pelayanan Pengaruhnya Terhadap Keputusan Pembelian Spring Bed Comforta.

16. Kivela, J., Inbakaran, R., \& Reece, J. (1999). Consumer research in the restaurant 
environment, part 1: A conceptual model of dining satisfaction and return patronage. International Journal of Contemporary Hospitality Management, Vol.11, No.5, 205

17. Kotler, Philip. 2012. Manajemen Pemasaran (Analisis, Perencanaan, Implementasi dan Pengendalian). Jakarta: Erlangga.

18. Kotler, P., \& K.L. Keller. (2013). Manajemen Pemasaran Jilid 1. (Terjemahan Bob Sabran). Cetakan Ketigabelas. Jakarta: Erlangga. (Edisi asli diterbitkan tahun 2009 oleh Pearson Education Inc. New Jersey Upper Saddle River).

19. Kotler \& Amstrong, 2012, Prinsip Prinsip Pemasaran jilid 1, Edisi 8, Jakarta: Erlangga.

20. Laksanam 2013, Manajemen Pemasaran Edisi Kesebelas Jilid 2. Jakarta

21. Moenir, A. S. 2015. Manajemen Kualitas pelayanan Umum di Indonesia. Jakarta: Bumi Aksara.

22. Mowen, J. C., \& M. Minor. 2012. Perilaku Konsumen Jilid I. (Terjemahan Lina Salim). Jakarta: Erlangga. (Edisi asli diterbitkan tahun 2001 oleh Harcourt College Publisher).

23. Mussry, 2014. Manajemen Pemasaran, Analisa dan Strategi. Edisi Kelima, Jakarta: Erlangga.

24. Nazwa Pandora, 2002,Pengaruh harga dan Kualitas pelayanan jasa terhadap keputusan pembelian pada JNE cabang surakarta

25. Nela, 2012, Prinsip Pemasaran, Jilid 1, Edisi Ketiga, Jakarta : Penerbit Erlangga

26. Parasuraman, A., V. A. Zeithaml, dan L.L. Berry, 2018, SERVQUAL: A Multiple-Item Scale for Measuring Consumer Perceptions of Service Quality, Journal of Retailing, Vol. 64, No. 1.

27. Qin, H., Prybutok, V.R., and Zhao, Q.2012, "Perceivd service quality in fast food restaurant: Empirical evidence from china", International Journal oof Quality and Reliability Management, Vol. 27, No.4,

28. Ryu, K., \& Han, H. 2013. Influence of the quality of food, service, and physical environment on customer satisfaction in quick-casual restaurants: Journal of Hospitality and Tourism Research, Vol. 3, No.3

29. Sarini Kodu, 2013, Harga, Kualitas produk Dan Kualitas pelayanan Pengaruhnya Terhadap Keputusan Pembelian Mobil Toyota Avanza
30. Setiadi, 2015. Perilaku Konsumen: Pendekatan Praktis Disertai Himpunan Jurnal Penelitian. Yogyakarta

31. Simamora, H. 2014. Manajemen Pemasaran Internasional Jilid II. Jakarta: Salemba Empat.

32. Suharsimi Arikunto, 2013 Teori Pengambilan sampel untuk penelitian, Jakarta: Bumi Aksara, 2013

33. Situmorang, Ginting, 2013, Metode Penelitian Kuantitatif, Libery, Yogyakarta

34. Sunyoto. 2013. Teori Kuisioner \& dan Analisis Data. Yogyakarta. Liberty.

35. Sudjana, 2014, Metode Penelitian Statistik, Jakarta : Bumi Aksara, 2014

36. Sugiyono. 2015, Metode Penelitian Administrasi. CV. Alfabeta, Bandung, 2015

37. Supirman, 2016,Pengaruhkualitas produk, harga dan lokasi terhadap keputusan pembelian konsumen pada Eramart Sentosa Samarinda

38. Suryani. 2015. Kualitas pelayanan. Bandung: Alfabeta.

39. Tjiptono, F., \& G. Chandra. 2015. Service, Quality \& Satisfaction. Yogyakarta:

40. Tjiptono, F. 2014. Manajemen Jasa. Yogyakarta: Andi. Tjiptono, F. (2011). Pemasaran Jasa. Malang: Bayumedia Publishing.

41. Umar, 2015, Prinsip Metodologi Penelitian Kuantitatif, Jakarta:Erlangga.

42. Uswatun Chasanah, 2019, Pengaruh Kualitas produk, Kualitas pelayanan dan lokasi terhadap Keputusan pembelian Konsumen Honda Yogyakarta.

43. Utomo dan Trisnowati 2017, Pengaruhkualitas produk terhadap keputusan pembelian Indo Mart Surabaya.

44. Wijaya, 2013, Manajemen Pemasaran, Bumi Aksara, Jakata.

45. Wood, M. B. 2014,. Buku Panduan Perencanaan Pemasaran, Edisi Ketiga. (Terjemahan Benyamin Molan). Jakarta: PT. Indeks. (Edisi asli diterbitkan tahun 2008 oleh Pearson Education Inc. New Jersey Upper Saddle River).

How to cite this article: Ahmad Rasyiddin, Endang Sulistya Rini, Fadli. The influence of service quality, product quality, price and promotion on Ayam Penyet Jakarta (APJ) purchase decisions on SM Raja Medan Branch. International Journal of Research and Review. 2022; 9(1): 392-398. DOI: https://doi.org/10.52403/ijrr.20220146 